\title{
Serum-, TPA-, and Ras-induced expression from Ap-1/Ets-driven promoters requires Raf-1 kinase
}

\author{
Joseph T. Bruder, Gisela Heidecker, and Ulf R. Rapp \\ Laboratory of Viral Carcinogenesis, National Cancer Institute, Frederick Cancer Research and Development Center, \\ Frederick, Maryland 21702-1201 USA
}

Raf-1 serine-threonine protein kinase has the hallmarks of a critical switch that connects growth factor receptor activation at the cell membrane with transcriptional events in the nucleus. We show by use of Raf-1 dominant-negative mutants that Raf-1 is required for serum-, TPA-, and Ras-induced expression from the oncogene-responsive element in the polyomavirus enhancer. The minimal region of Raf-1 that displays this dominant-negative phenotype (Raf-C4) contains a cysteine finger motif. Raf-C4 appears to function by titrating out a Raf-1-activating factor that is induced by Ras following serum or TPA treatment of NIH-3T3 cells. In addition, we show that Raf-1 and Ras cooperate in trans-activation through the oncogene-responsive element and that the cysteine-rich region is necessary for this effect.

[Key Words: Raf-1; v-Ha-Ras; proto-oncogene; signal transduction]

Received October 28, 1991; revised version accepted February 11, 1992.

The Raf-1 proto-oncogene product is thought to play a central role in signal transduction. Stimulation of growth factor receptors or mitogen treatment of cells results in an increase in Raf-1 kinase activity and Raf-1 phosphorylation leading to an altered mobility on SDSpolyacrylamide gels (Morrison ct al. 1988; Rapp 1991). Following mitogenic stimulation, this activated form of Raf-1 translocates to the perinuclear area and the nucleus (Rapp et al. 1988a; Olah et al. 1991). v-raf-Transformed cells contain a fraction of kinase-active gag-raf fusion protein as well as activated endogenous Raf- 1 in the nucleus, even under serum-starved conditions (U. Rapp and W. Anderson, unpubl.). Expression of v-Raf or activated, mutant versions of Raf-1 trans-activate transcription from the oncogene-responsive element in the polyomavirus enhancer (Rapp et al. 1988b; Wasylyk et al. 1989a), from the c-fos promoter (Kaibuchi et al. 1989; Jamal and Ziff 1990), and from the Egr-1 promoter (Qureshi et al. 1991). In addition, these activating mutations convert c-raf-1 to a transforming oncogene (Rapp et al. 1988b; Stanton et al. 1989; Heidecker et al. 19901. These observations suggest that Raf- 1 transmits a signal from the plasma membrane to the nucleus where it functions to change the expression of genes involved in growth control.

Transcription from the oncogene-responsive element in the polyomavirus enhancer can be activated by serum, TPA, and diverse classes of oncogenes (Wasylyk et al. 1988). The oncogene-responsive element contains an AP-1-binding site and an overlapping Ets-binding site. Point mutations in either motif dramatically reduce transcriptional activation by serum and TPA stimulation, by the cytoplasmic oncogenes $v$-Src, polyoma middle $T$ antigen, v-Ras, v-Raf, and $v-$ Mos, and by the nuclear proto-oncogene products c-Fos, c-Jun, JunB, Ets-1, and Ets-2, which bind to and stimulate transcription from their respective binding sites in this element $/ \mathrm{Wa}$ sylyk et al. 1989a,b, 1990). It is likely that the cytoplasmic oncogene products function by increasing the transcription-inducing activity of the nuclear proto-oncogene products that bind to this element.

Raf-1 and Ras have been implicated in the signal transduction downstream of growth factor receptors and membrane-bound tyrosine kinase oncoproteins. Presumably, there is convergence in the signaling pathways through which membrane-bound activators exert their effect, because Ras inhibition blocks induction of DNA synthesis, cell proliferation, and transformation by serum, TPA, and a diverse repertoire of activated tyrosine kinases (Noda et al. 1983; Mulcahy et al. 1985; Smith et al. 1986; Cai et al. 1990). The positioning of Raf-1 as an essential cytoplasmic signal transducer downstream of Ras and membrane-associated tyrosine kinases has been established using Ras revertant cell lines (Noda et al. 1983; Rapp et al. 1988b), inhibitory Ras antibodies (Huleihel et al. 1986; Smith et al. 1986), and antisense and dominant-negative Raf-1 mutants (Kolch et al. 1991).

Raf family members contain three highly conserved regions: CR1, CR2, and CR3 (Fig. 1A). CR1 contains a cysteine finger motif, CR2 contains many serine and threonine residues, and CR3 is the kinase domain. CR1 
Bruder et al.

A

Raf-wt

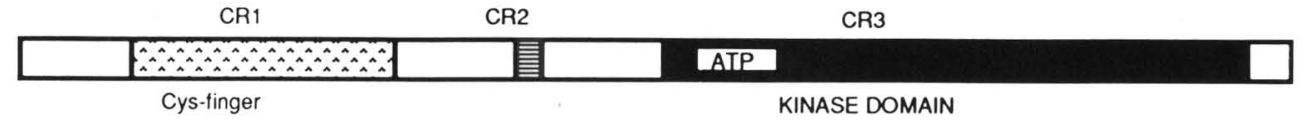

Raf-301

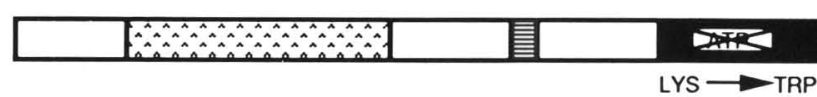

RAF-BXB

B

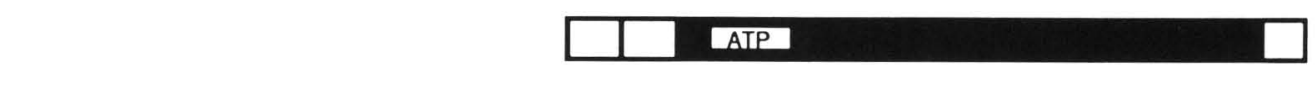

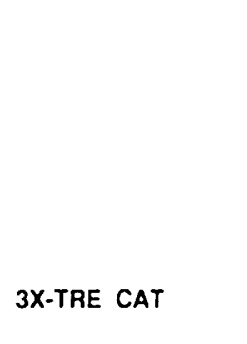

PBL-CAT

pB-4X

PAB- $4 X$
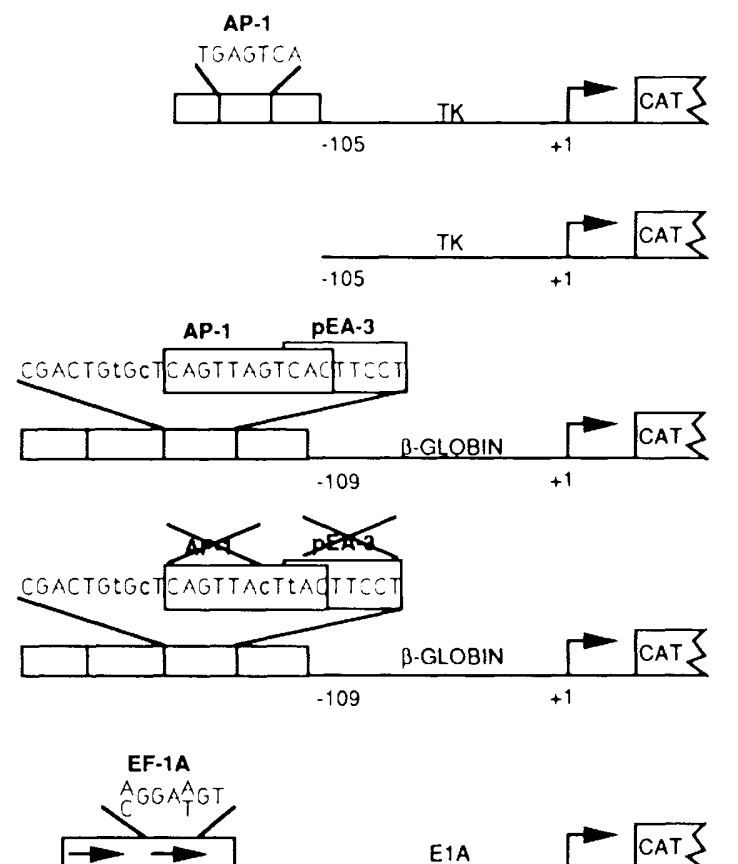

$A+B w t$

$A+B$ mut

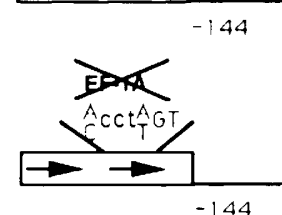

2

12

$<1$

$<1$

Relative CAT activity

3 T3

HepG2

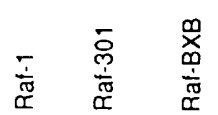
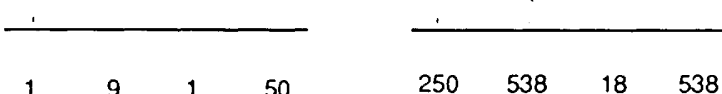

$\begin{array}{llll}250 & 538 & 18 & 538\end{array}$

2

$\begin{array}{lll}3 & 1 & 4\end{array}$

(1)

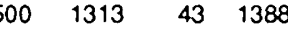

$\begin{array}{llll}5 & 7 & 5 & 6\end{array}$

$<1<1<1<1$

$20 \quad 49 \quad 3$

45

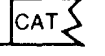

$<<1<1$

CAT $<1<1<1<1$

2

2

3

Figure 1. Identification of activating and dominant-negative mutants of Raf-1. (A) A schematic representation of Raf expression constructs tested for trans-activation. The positions of the conserved regions, CR1, CR2, and CR3, are indicated. Raf-301 contains a single-amino-acid substitution $(\mathrm{K} \rightarrow \mathrm{W})$ at position 375 in the ATP-binding site of Raf- 1 (Heidecker et al. 1990). Raf-BXB is an in-frame deletion of amino acids 26-302 in the regulatory region of Raf-1. (B) Schematic representations of the reporter constructs. These reporter constructs were transfected into NIH-3T3 or HepG 2 cells with $5 \mu \mathrm{g}$ of an RSV-LTR expression vector encoding wild-type or mutant Raf-1 proteins. Cells were harvested $48 \mathrm{hr}$ post-transfection and assayed for CAT activity. Columns at right indicate the average relative CAT activity from at least four separate experiments. The CAT activity of the 3X-TRE CAT reporter plasmid transfected alone was arbitrarily set at 1 . 
and CR2 appear to be involved in regulation of Raf-1 activity, as deletions or insertions within these regions activate Raf-1-transforming (Rapp et al. 1988b; Stanton et al. 1989; Heidecker et al. 1990) and trans-activation activities (Wasylyk et al. 1989a). It has been proposed that phosphorylation in CR2 and binding of a mitogenstimulated factor to CR1 may trigger the activation of Raf-1 (Rapp et al. 1988a; Heidecker et al. 1990; Rapp 1991).

We have explored the Raf- 1 dependence on serum- and TPA-induced transcriptional activation of genes driven by AP-1 - and Ets-binding motifs using various Raf-1 mutants in cotransfection assays. Our results reveal that Raf- 1 activity is regulated by a factor that activates Raf- 1 through interactions with the cysteine finger motif. Our experiments suggest that the activity of this factor is induced by Ras, following serum and TPA stimulation of NIH-3T3 cells. These findings establish the mechanism by which Ras activates transcription of target genes, identify Raf- 1 as a Ras effector kinase, and suggest an important pathway in tumorigenesis.

\section{Results}

A dominant-negative Raf-1 mutant blocks basal levels of expression from Ap-1/Ets-driven promoters

To assess the role of Raf- 1 in activation of transcription through AP-1- and Ets-1-binding sites, we utilized three different reporter constructs (Fig. 1B). pB4X contains four copies of the oncogene-responsive element from the polyomavirus enhancer inserted upstream from the $\beta$-globin promoter fused to the chloramphenicol acetyltransferase (CAT) gene. pAB4X is similar to pB4X, except for two point mutations in the AP-1- and Ets-1-binding sites (Wasylyk et al. 1989a). 3X-TRE CAT contains three tandem AP-1 sites from the collagenase promoter inserted upstream of the TK promoter fused to CAT (Angel et al. 1987). A + B wt contains two binding sites for EF$1 \mathrm{~A}$ cloned upstream from the E1A promoter fused to CAT (Bruder and Hearing 1989). The EF-1A motifs are binding sites for Ets-1- and Ets-related proteins (G.M. Bolwig, J.T. Bruder, T. Papas, D. Hodge, A. Seth, and P. Hearing, unpubl.). Initially, we analyzed the effects of two Raf-1 mutants on trans-activation of these reporters (Fig. 1A). Raf-BXB carries a large deletion in the aminoterminal regulatory domain of Raf- 1 . This deletion renders Raf-1 constitutively activated with regard to transformation of NIH-3T3 cells. Raf-301 carries a singleamino-acid substitution (lysine to tryptophan) in the Raf-1 ATP-binding site. Raf-301 is nontransforming and functions as a dominant-negative mutant with regard to cell proliferation and transformation (Kolch et al. 1991). Raf-1 or, more effectively, the transforming mutant Raf$\mathrm{BXB}$ trans-activated promoters containing AP-1-binding sites (pB4X and 3X-TRE CAT) but not promoters containing Ets-1-binding motifs $(\mathrm{A}+\mathrm{B} \mathrm{wt})$ in NIH-3T3 cells (Fig. 1). As expected, Raf-301 did not trans-activate any of the reporters. In HepG2 cells where the basal levels of reporter gene expression were much higher, Raf- 1 and Raf-BXB only marginally trans-activated all three pro- moters. Interestingly, cotransfection of a vector that expresses the kinase negative mutant, Raf-301, dramatically blocked the activity of all three promoters. A more limited degree of inhibition (40\%) was observed by use of antisense Raf-1 vectors (data not shown). Reporters with point mutations or deletions in the AP-1-or Ets-binding sites were not Raf responsive, indicating specificity for Raf- 1 activation. These results suggest that endogenous Raf- 1 is constitutively active in HepG 2 cells and the Raf301 mutant functions by blocking endogenous Raf- 1 activity. The differences observed on Raf-1 activity between NIH-3T3 and HepG2 cells are consistent with the constitutive expression of a Raf-1 activator in HepG2 cells.

The amino-terminal regulatory region of Raf-1 is necessary and sufficient for the dominant-negative phenotype

To determine which region of Raf-301 is important for blocking the activity of endogenous Raf-1, we tested a series of Raf-1 mutants for their ability to block basal levels of expression from the polyoma reporter construct following cotransfection into HepG2 cells (Fig. 2). Raf expression constructs carrying progressive deletions through the kinase domain and CR2, Raf-Cl through Raf-C4, efficiently blocked endogenous Raf-l activity. Raf-C4 encodes the amino-terminal 257 amino acids of Raf-1, which contains CR1. Raf-C4 blocked basal levels of CAT expression more efficiently than did any of the other mutants. Inhibition by Raf-C4 was specific for expression from promoters driven by Ap-1/Ets-binding sites, because Raf-C4 did not block expression from promoters driven by the SV40 enhancer or the Rous sarcoma virus long terminal repeat (RSV-LTR; data not shown). Cotransfection of vectors expressing Raf-BXB-301 or Raf$\mathrm{N} 1$, both of which lack the amino-terminal cysteine-rich domain and are expressed efficiently, had no effect on transcription in HepG2 cells. To ensure that the Raf-C4 protein blocks AP-1/Ets-dependent transcription and to determine whether the cysteine-rich region within CRl is necessary for this activity, we tested the ability of Raf-C4pml7 to block AP-1/Ets-driven expression in HepG2 cells. Raf-C4pm17 contains a single-amino-acid substitution (cysteine to serine at position 168) within the Raf-C4 cysteine-rich region. This substitution strongly decreases the dominant-negative effect of RafC4 (Fig. 2C). We conclude that the amino-terminal domain confers the dominant-negative phenotype upon the cRaf-301 protein. The lack of activity of Raf-C4pm17 suggests that either the mutation affects protein stability or that the conserved cysteine finger motif in Raf- 1 is necessary for interactions with upstream regulatory factors. We have recently described a carboxy-terminal deletion mutant similar to Raf-C4, termed pHRC, which interferes with viability and/or proliferation of NIH-3T3 cells (Kolch et al. 1991). Like Raf-C4, pHCR contains the cysteine finger motif but not CR2 and CR3. Thus, it appears that the Raf-1 cysteine finger motif may be important in regulating both mitogen-induced transcriptional activation and cell growth. 
Figure 2. The amino-terminal region of Raf-1 is necessary and sufficient for the dominant-negative phenotype. (A) Schematic representation of Raf-1 and Raf-1 mutant expression constructs. Raf-1, Raf301, and Raf-BXB are the same as in Fig. 1. Raf-C1 through Raf-C4 are progressive carboxy-terminal deletions of Raf-1. Raf-N1 is an amino-terminal deletion of Raf- 1 . Raf-BXB-301 is the ATP-binding site mutant $(\mathrm{K} \rightarrow \mathrm{W}$ at position 375$)$ in the Raf$\mathrm{BXB}$ background. Raf-BXB-C1 is a carboxyterminal deletion of Raf-BXB. Raf-C4pm 17 is the same as Raf-C4 except it contains a single-amino-acid substitution /Cys-168 to Ser). (For details on the construction of these mutants, see Materials and methods.) $(B)$ Five micrograms of the indicated RSV-LTR expression vector, encoding the wild-type or mutant Raf proteins illustrated in $A$, was cotransfected with $1 \mu \mathrm{g}$ of pB4X into HepG2 cells. (C) HepG2 cells were cotransfected with $0.5 \mu \mathrm{g}$ of RSVRaf-C4 or RSV-Raf-C4pm 17 and $1 \mu g$ of $\mathrm{pB} 4 \mathrm{X}$. The level of CAT expression was determined $48 \mathrm{hr}$ after transfection. The standard deviation of the mean values is indicated by error bars.

A

Raf- 1

Rai-301

Raf $-C_{1}$

Raf-C2

Raf -C3

Raf-C 4

Raf $-N_{1}$

RAF-BXB

RAF-BXB-301

$\mathrm{RAF}-\mathrm{B} \times \mathrm{B}-\mathrm{C} 1$

Raf-C4pm 17

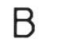

B
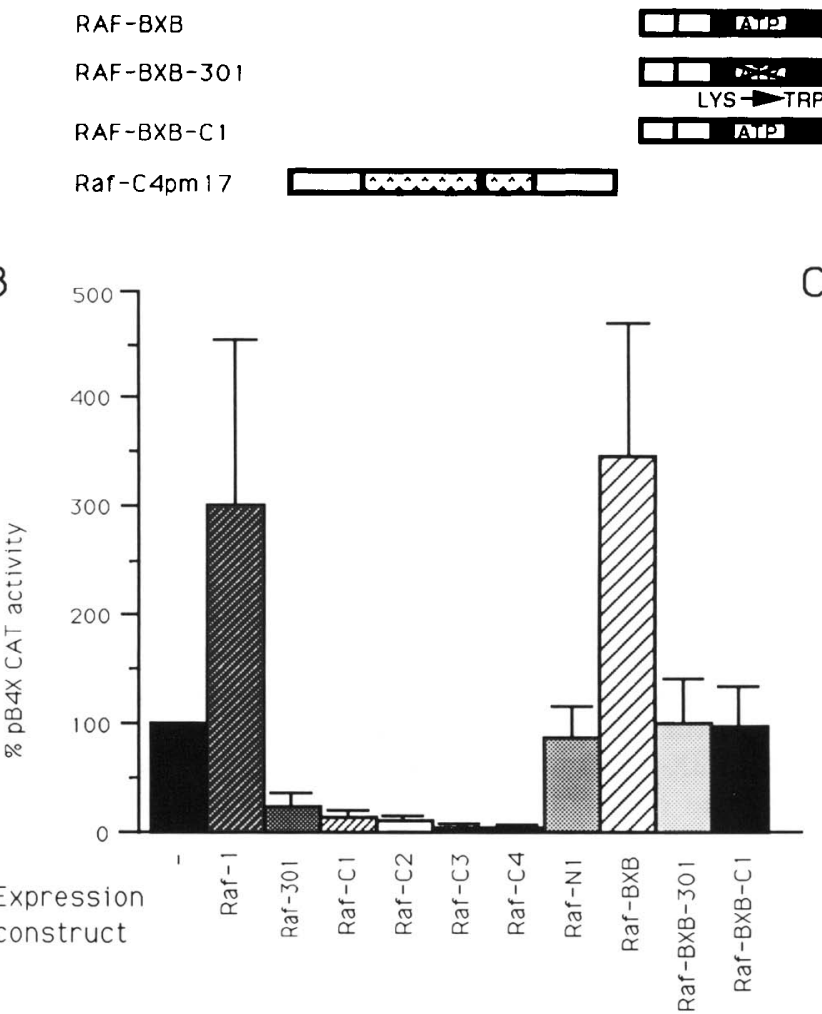

CR3

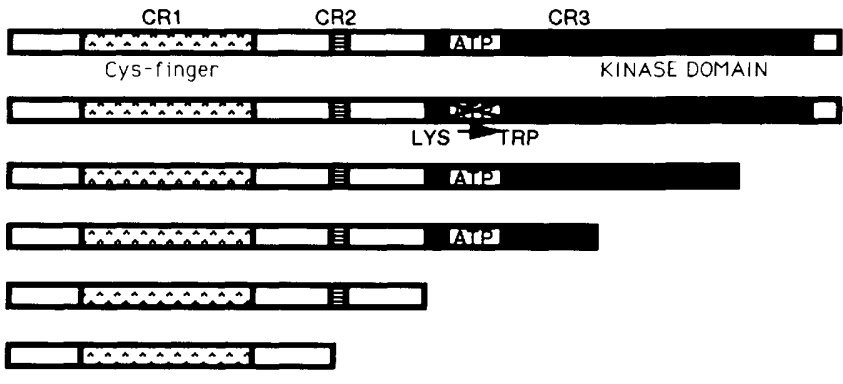

D国— AIP

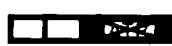

LYS $\rightarrow$ TRP

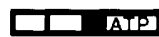

The Raf-C4 dominant-negative mutant blocks serumand TPA-induced expression from the oncogene-responsive element and functions at the level of Raf-1 activation

The dominant-negative mutants were used to determine whether Raf-1 is necessary for TPA- and serum growth factor-induced expression from the oncogene-responsive element. pB4X CAT expression was induced 12-fold by serum or TPA stimulation of NIH-3T3 cells. Cotransfection of vectors that express Raf-301 or the Raf-C4 mutant with the $\mathrm{pB} 4 \mathrm{X}$ reporter significantly reduced the inducibility of this construct by serum and TPA, strongly suggesting that Raf- 1 is required for serum- and TPA-induced transcriptional activation (Fig. 3).

What is the mechanism by which Raf-C4 blocks transcriptional activation from the oncogene-responsive ele- ment? Raf-C4 may block a transition step between inactive and active Raf-1. Alternatively, Raf-C4 may block the interaction between Raf-1 and its substrate. Another possibility is that Raf-C4 does not block Raf-1 but another factor involved in transcriptional activation. To test whether Raf-C4 is blocking Raf-1 activity, we cotransfected NIH-3T3 cells with pB4X, RSV-Raf-1, and a vector control or RSV-Raf-C4 (Fig. 4). As observed previously, Raf-1 trans-activated CAT expression two- to fivefold. A two- to fourfold block in Raf-1 activity was consistently observed when a twofold excess of the RSVRaf-C4 mutant was cotransfected with RSV-Raf-1 into $\mathrm{NIH}-3 \mathrm{~T} 3$ cells, indicating that the Raf-C4 mutant does block Raf-1 function.

The amino-terminal half of Raf- 1 is thought to have a negative regulatory function as its deletion activates kinase and transforming activities of Raf- 1 . Interaction of 


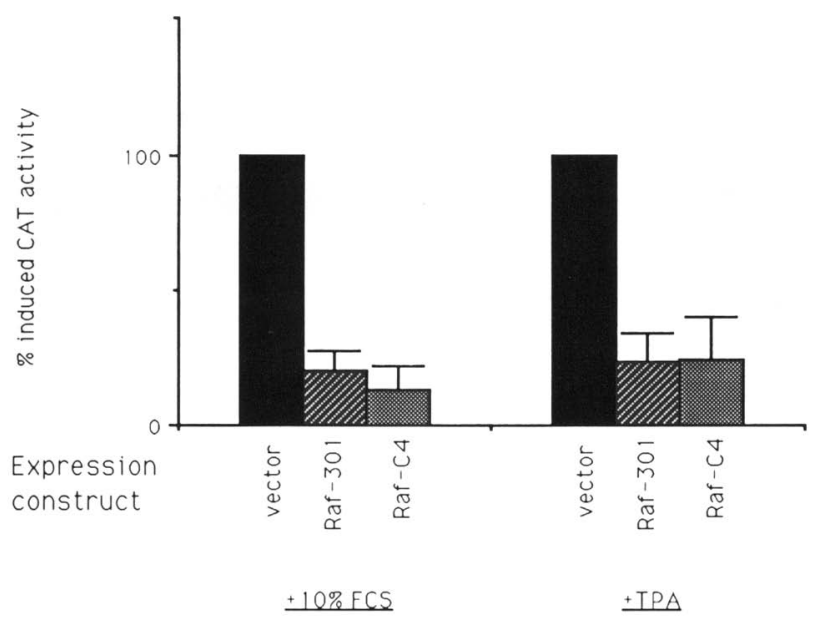

Figure 3. Raf-1 is necessary for serum- and TPA-induced expression from the oncogene-responsive element in the polyomavirus enhancer. NIH-3T3 cells were cotransfected with $1 \mu \mathrm{g}$ of $\mathrm{pB} 4 \mathrm{X}$ and $5 \mu \mathrm{g}$ of vector control (pkRSPA), RSV-Raf-301, or RSV-Raf-C4. Following transfection, the cells were maintained in media containing $0.3 \%$ fetal calf serum. Forty-two hours after transfection, the cells were induced with $10 \%$ FCS or TPA $(100$ $\mathrm{ng} / \mathrm{ml}$ ) for $6 \mathrm{hr}$. At $48 \mathrm{hr}$ post-transfection, cells were harvested and extracts were analyzed for CAT expression. The amount of CAT activity detected in the induced vector control /12-fold over uninduced) was set at $100 \%$. The standard deviation of the mean values is indicated by error bars.

this domain with upstream Raf-l regulators is a likely mechanism for the activation of Raf-1 kinase. Consistent with this model for Raf-1 activation is the finding that the dominant-negative mutants Raf-301 (data not shown) and Raf-C4 (Fig. 4) did not block the transcriptional activity of Raf-BXB, which lacks this negative regulatory domain. In addition, Raf-pm 17, which carries a single-amino-acid substitution in the Raf-l cysteine finger motif (Cys-168 to Ser), reproducibly trans-activated two- to threefold better than Raf-1, and cotransfection of RSV-Raf-pm 17 with RSV-Raf-C4 did not result in a decrease in trans-activation by Raf-pm 17. The inability of cotransfected Raf-C4 to block trans-activation by Rafpml 17 strongly suggests that the cysteine finger motif in Raf-C4 is important for blocking Raf-1 function. This result, along with our finding that Raf-C4 did not block Raf-BXB activity, indicates that Raf- $\mathrm{C} 4$ probably blocks a Raf activation event and does not compete for substrate utilization.

\section{Raf-1 is necessary for trans-activation by Ras}

Ras appears to lie in a signal transduction pathway downstream of growth factor receptors and upstream of Raf (Mulcahy et al. 1985; Huleihel et al. 1986; Smith et al. 1986). We have observed previously that the Raf-1 dominant-negative mutant p301-1 and Raf-1 antisense constructs blocked transformation by $\mathrm{v}$-Ras (Kolch et al. 1991). v-Ras also activates transcription from the oncogene-responsive element in the polyomavirus enhancer
(Wasylyk et al. 1988, 1989b). To determine whether Raf-1 mediates trans-activation by Ras, we looked at the ability of Raf-C4 to block Ras-induced activation through the oncogene-responsive element (Fig. 5A). $\mathrm{v}-\mathrm{Ha}$-Ras efficiently trans-activated pB4X CAT expression, and Raf-C4 completely blocked Ras-induced expression. These results demonstrate that Raf-1 is necessary for trans-activation by Ras. Mos trans-activation was not blocked by Raf-C4, indicating that Mos functions downstream of Raf or in a different pathway. Dose response determination showed a linear dose dependence for inhibition of $\mathrm{v}$-Ha-Ras-induced reporter expression by Raf-C4 (Fig. 5B). This result is consistent with titration by Raf-C4 of a rate-limiting activator of Raf- 1 .

Because v-Ha-Ras activates transcription from the oncogene-responsive element in the polyomavirus enhancer by activating Raf-1, we expect $\mathrm{v}-\mathrm{Ha}$-Ras and Raf-1 to cooperate in trans-activation when cotransfected into NIH-3T3 cells with the polyomavirus reporter. Cotransfection of NIH-3T3 cells with pB4X and v-Ha-Ras or RSV-Raf-1 led to a modest increase in expression from pB4X (Fig. 6). However, cotransfection of cells with pB4X, v-Ha-Ras, and RSV-Raf- 1 resulted in a dramatic increase in CAT expression. The levels of CAT expression observed in the $\mathrm{v}-\mathrm{Ha}$-Ras/RSV-Raf- 1 cotransfection are similar to the levels obtained with the fully activated Raf-1 mutant, Raf-BXB. We have also observed cooperation between Raf-1 and Ras in Ras-transformed NIH-3T3 cells (data not shown). v-Ha-Ras did not synergize with activated Raf, Raf-BXB, or v-Mos (Fig. 6A), and no cooperation was observed when Raf-1 was cotransfected with PM-1 or RSV-Raf-BXB (data not shown). Therefore, it seems likely that as with serum and TPA, Ras regulates the activity of Raf-1. The finding that Raf-BXB does not synergize with Ras is consistent with this notion, because the regulatory region of Raf- 1 has been deleted in Raf-BXB. Ras/Raf synergy at the transcriptional level appears to result ultimately in cell transformation, as we have observed cooperative interactions between Raf-1 and Ras at the level of transformation as well /A. Cuadrado, T. Fleming, J. Bruder, S. Aaronson, and U. Rapp, unpubl.).

\section{The cysteine-rich region of Raf-1 is necessary for Raf/Ras cooperation}

Using a dominant-negative Ras mutant we have demonstrated recently that Ras is necessary for both serum- and TPA-induced activation of $\mathrm{pB} 4 \mathrm{X}$ CAT expression (J. Troppmair, J.T. Bruder, H. App, H. Cai, J. Szeberényi, G.M. Cooper, and U.R. Rapp, in prep.). Because Ras functions by activating Raf- 1 (Fig. 5) and the cysteine-rich region of Raf-1 appears to be necessary for activation of Raf-1 (Figs. 2-4), we were interested in determining whether the cysteine finger motif of Raf-1 was necessary for activation by Ras. To address this issue we cotransfected NIH-3T3 cells with the pB4X reporter $\mathrm{v}-\mathrm{Ha}$-Ras and the cysteine finger motif mutant RSV-Raf-pml7 (Fig. 6B). As shown previously, Raf-pm 17 trans-activated better than Raf-1 but not as efficiently as Raf-BXB or the 
A

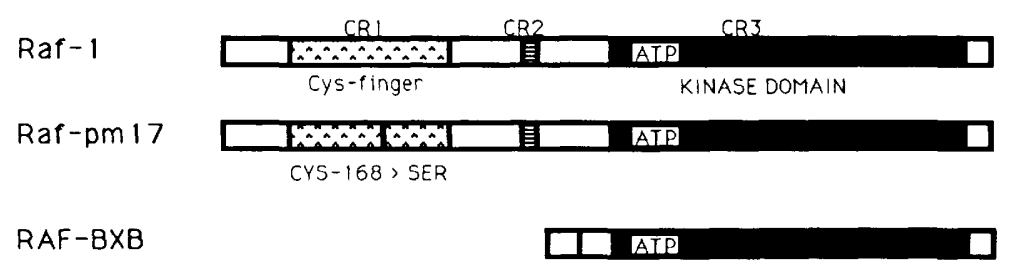

B

Figure 4. The Raf-C4 dominant-negative mutant functions at the level of Raf activation. (A) Schematic representation of Raf-1 and Raf- 1 mutant proteins. Raf-1 and Raf-BXB are the same as in Fig. 1. Raf-pml7 carries a single-amino-acid substitution $(\mathrm{C} \rightarrow \mathrm{S})$ in the last cysteine of the cysteine finger motif of Raf- 1 and is expressed from the RSV-LTR. $(B)$ NIH-3T3 cells were cotransfected with $1 \mu \mathrm{g}$ of $\mathrm{pB} 4 \mathrm{X}$ and $5 \mu \mathrm{g}$ of the indicated expression vectors. The vector control is the parent vector pkRSPA (Dorn et al. 1990). The level of CAT expression was determined from cell extracts harvested $48 \mathrm{hr}$ post-transfection. The standard deviation of the mean values is indicated by error bars.

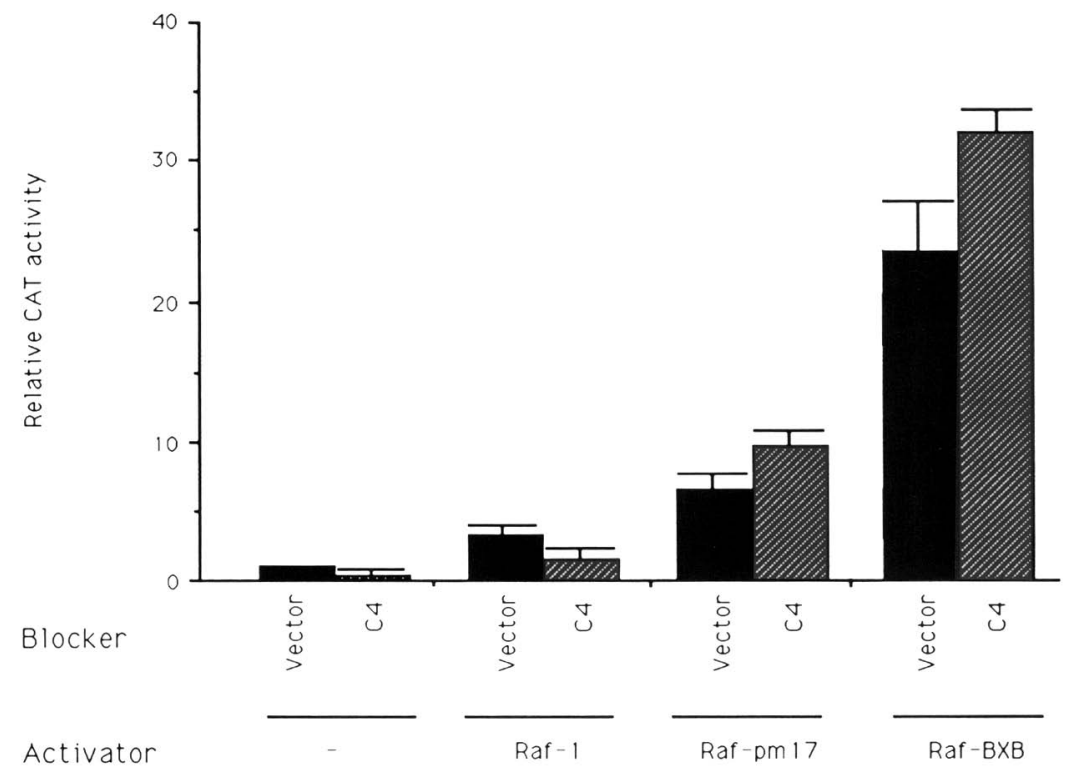

combination of $\mathrm{v}-\mathrm{Ha}-\mathrm{Ras}$ and Raf-1. Cotransfection of RSV-Raf-pm17 and v-Ha-Ras did not result in an increase in CAT expression relative to RSV-Raf-pm 17 alone. This result indicates that the cysteine finger motif is necessary for cooperation with Ras. A mutant, v-HaRas-V15, carrying a single inactivating amino acid substitution in v-Ha-Ras, did not trans-activate and did not cooperate with Raf-1. These results indicate that $\mathrm{v}-\mathrm{Ha}$ Ras activates transcription by modulating the activity of Raf- 1 through interactions with the cysteine-rich region of Raf-1. This interpretation is supported by the finding that Raf-C4pml7 is a poor inhibitor of Ras-induced trans-activation of $\mathrm{pB} 4 \mathrm{X}$ CAT expression (data not shown). Ras may bind directly to this region of Raf-1, resulting in an activation of Raf-1 kinase activity, although at present there is no evidence for a direct interaction between Ras and Raf-1. Alternatively, Ras may induce a factor that binds to and activates Raf- 1 through interactions with the cysteine finger motif.

\section{Discussion}

In this paper we have demonstrated that Raf-1 can transactivate promoters containing AP-1- and Ets-binding sites. Using Raf-1 dominant-negative mutants, we have shown that Raf-1 is necessary for basal levels of expression from Ap-1/Ets-driven promoters in HepG2 cells and for serum-, TPA-, and Ras-induced expression in NIH3 T3 cells. We have observed constitutive expression of a Raf- 1 activator in HepG 2 cells, which activates Raf- 1 through interactions with the amino-terminal, cysteinerich, regulatory domain. This activator appears to be induced by Ras following serum and TPA stimulation of resting NIH-3T3 cells.

In many receptor systems, stimulation of the receptor results in hyperphosphorylation of Raf-1, which correlates with an increase in Raf kinase activity. Therefore, phosphorylation-mediated activation of Raf-1 has received much attention. In fact, extracellular signal-regulated kinases (ERKs) have recently been shown to phosphorylate Raf-1 in vitro (Lee et al. 1991), and Raf-1 autophosphorylation has been observed on serine residues within the regulatory domain (D. Morrison, G. Heidecker, and U. Rapp, unpubl.). Our results do not exclude a catalytic mode of Raf-l activation involving posttranslational modification of the cysteine-rich region. However, because the activating factor can be titrated efficiently, the activity must be saturable. In addition, 
A

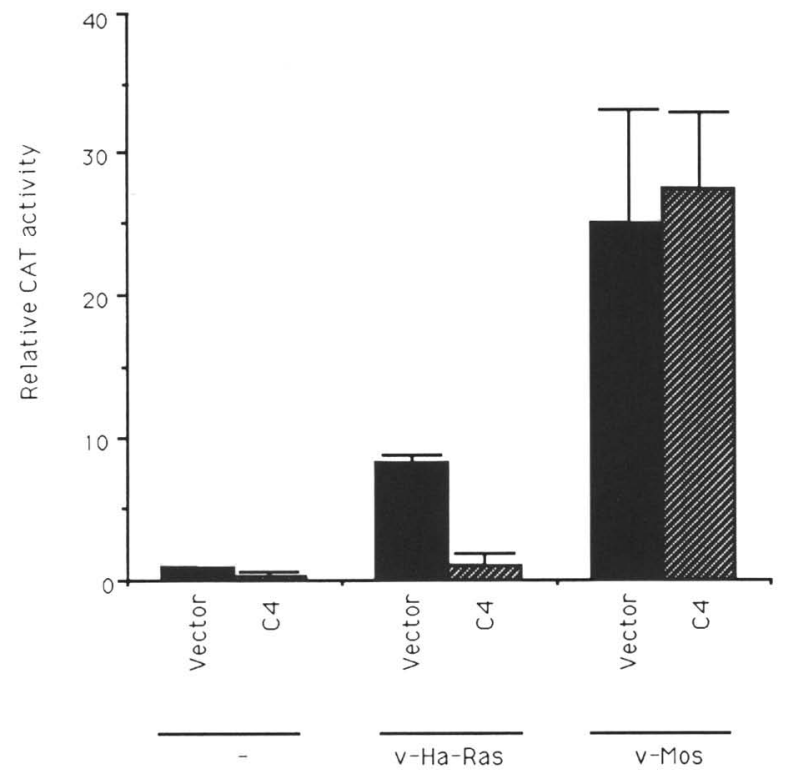

B

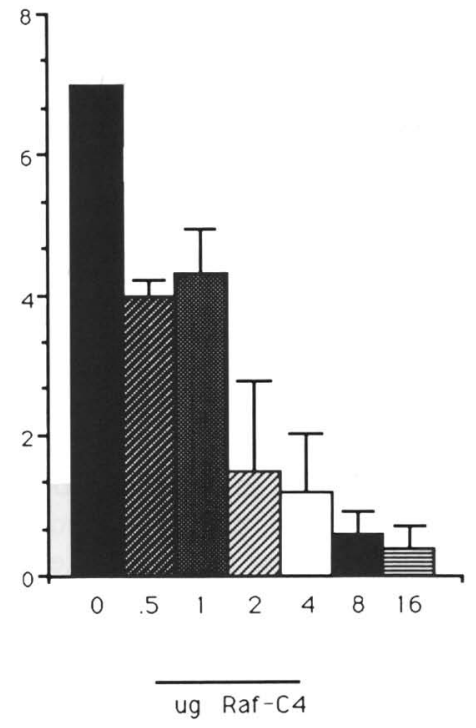

Figure 5. Raf-1 is necessary for trans-activation by v-Ha-Ras. (A) NIH-3T3 cells were cotransfected with $1 \mu \mathrm{g}$ of $\mathrm{pB} 4 \mathrm{X}$ and $5 \mu \mathrm{g}$ each of the indicated expression vectors. v-Ha-Ras expresses activated Ras from the SV40 carly promoter (Clanton et al. 1987), and pM-1 expresses v-Mos from the Moloney murine sarcoma virus (MSV)-LTR. (B) NIH-3T3 cells were cotransfected with $5 \mu \mathrm{g}$ of $v$-Ha-Ras and increasing concentrations of Raf-C4. The level of CAT expression was determined from cell extracts harvested $48 \mathrm{hr}$ post-transfection. The standard deviation of the mean values is indicated by error bars.
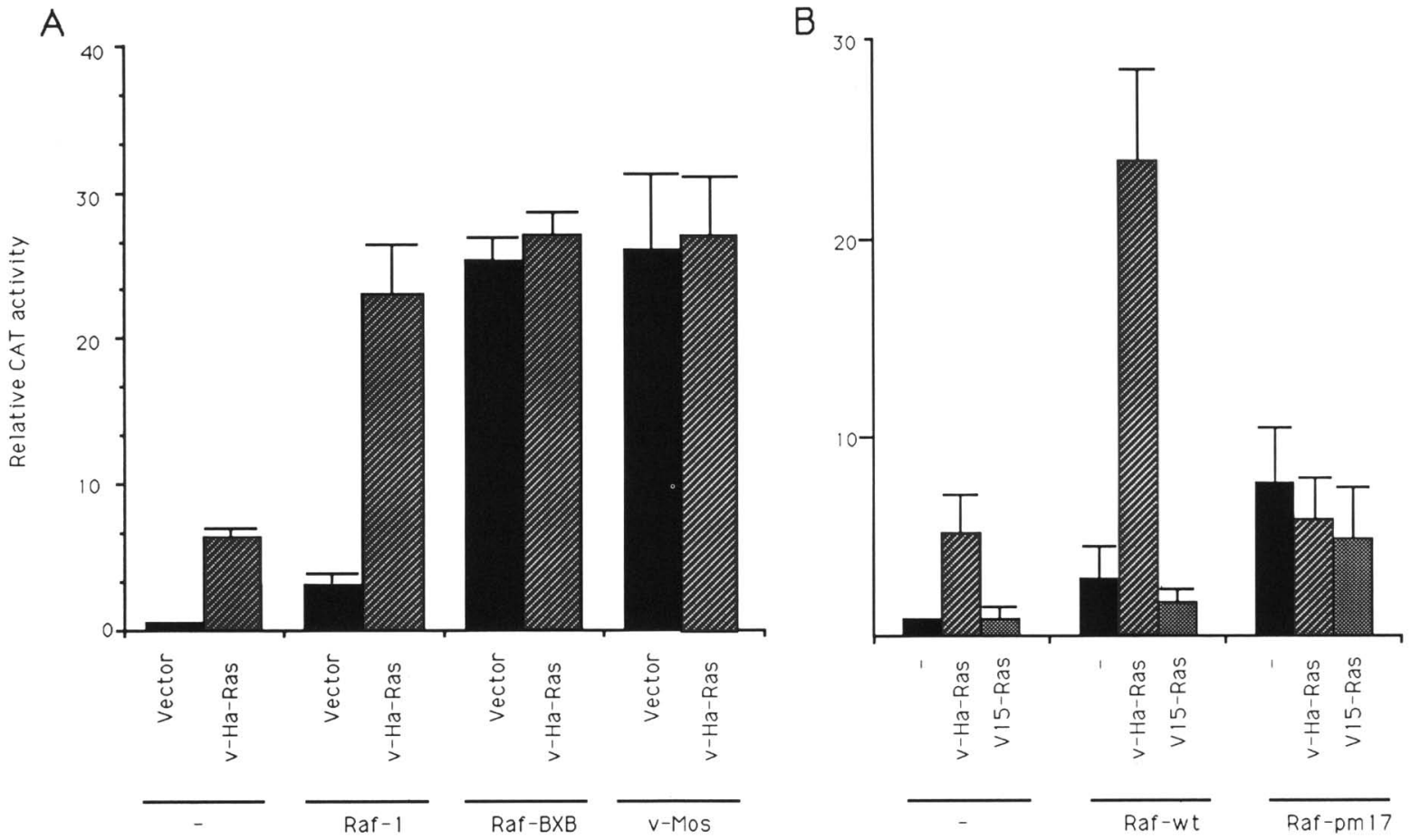

Figure 6. The cysteine finger motif of Raf- 1 is necessary for cooperative interactions with v-Ha-Ras. NIH-3T3 cells were cotransfected with $1 \mu \mathrm{g}$ of $\mathrm{pB} 4 \mathrm{X}$ and $5 \mu \mathrm{g}$ each of the indicated expression vectors. $\mathrm{v}$-Ha-Ras-V15 expresses a nontransforming mutant $\mathrm{v}$-Ras (Gly $\rightarrow$ Val at position 15) from the SV40 early promoter (Clanton et al. 1987). The level of CAT expression was determined from cell extracts harvested $48 \mathrm{hr}$ post-transfection. The standard deviation of the mean values is indicated by error bars. 
the finding that Raf-pm 17 is not subject to inhibition by Raf-C4 and does not cooperate with Ras argues against a simple phosphorylation-mediated activation of Raf- 1 in this system. Perhaps there are multiple independent mechanisms for Raf-l activation. Alternatively, both ligand binding and phosphorylation events may be necessary for full activation of Raf-1 kinase.

The simplest model for Raf- 1 activation that is consistent with the results presented here is illustrated in Figure 7. In quiescent cells, Raf-1 is held in an inactive conformation through intramolecular interactions or intermolecular interactions with a repressor. Upon stimulation of cells with growth factors or TPA, a Ras-induced factor binds to the cysteine finger of Raf-1, relieves the negative inhibition, and activates the Raf-1 kinase. Activation of Raf-1 results in transcriptional activation of specific target genes and, ultimately, to the stimulation of cell growth. According to this model, Raf-C4 blocks Raf activation by titrating out this putative Ras-induced factor and the finger mutant Raf-pm 17 is partially active as it assumes the inactive conformation less efficiently.
Comparison of the cysteine-rich region of Raf-l (CR1) with similar motifs in other proteins may lend insight into the mechanism of Raf-l activation. The cysteinerich region of Raf- 1 is similar to the phorbol ester-binding domain in protein kinase $\mathrm{C}$ (PKC) family members, $n$-chimaerin, and the unc-13 gene product /Coussens et al. 1986; Ahmed et al. 1990; Hall et al. 1990; Levin et al. 1990; Maruyama and Brenner 1991). The regions flanking the putative zinc fingers in each of these proteins share similar amino acids, which are not present in the zinc fingers of many transcription factors (Fig. 8). PKC is activated following phosphatidylserine-dependent diacylglycerol (DAG) binding to this cysteine finger motif. Studies using inducible Ras proteins and cells that express Ras at high levels demonstrate that Ras may play a role in DAG (Fleischman et al. 1986; Preiss et al. 1986; Lacal et al. 1987) and arachidonic acid production (BarSagi and Feramisco 1986). Taken together with the demonstration of G-protein coupling to phospholipase C (for review, see Bourne and DeFranco 1989), it is tempting to speculate that the Ras-induced factor that interacts with

Lnactive cRaf -1 kinase

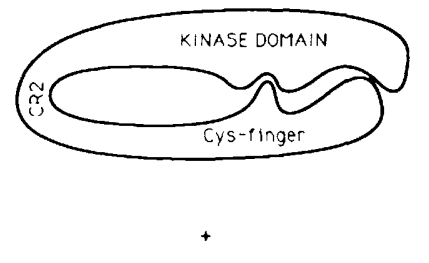

serum growth factors or TPA

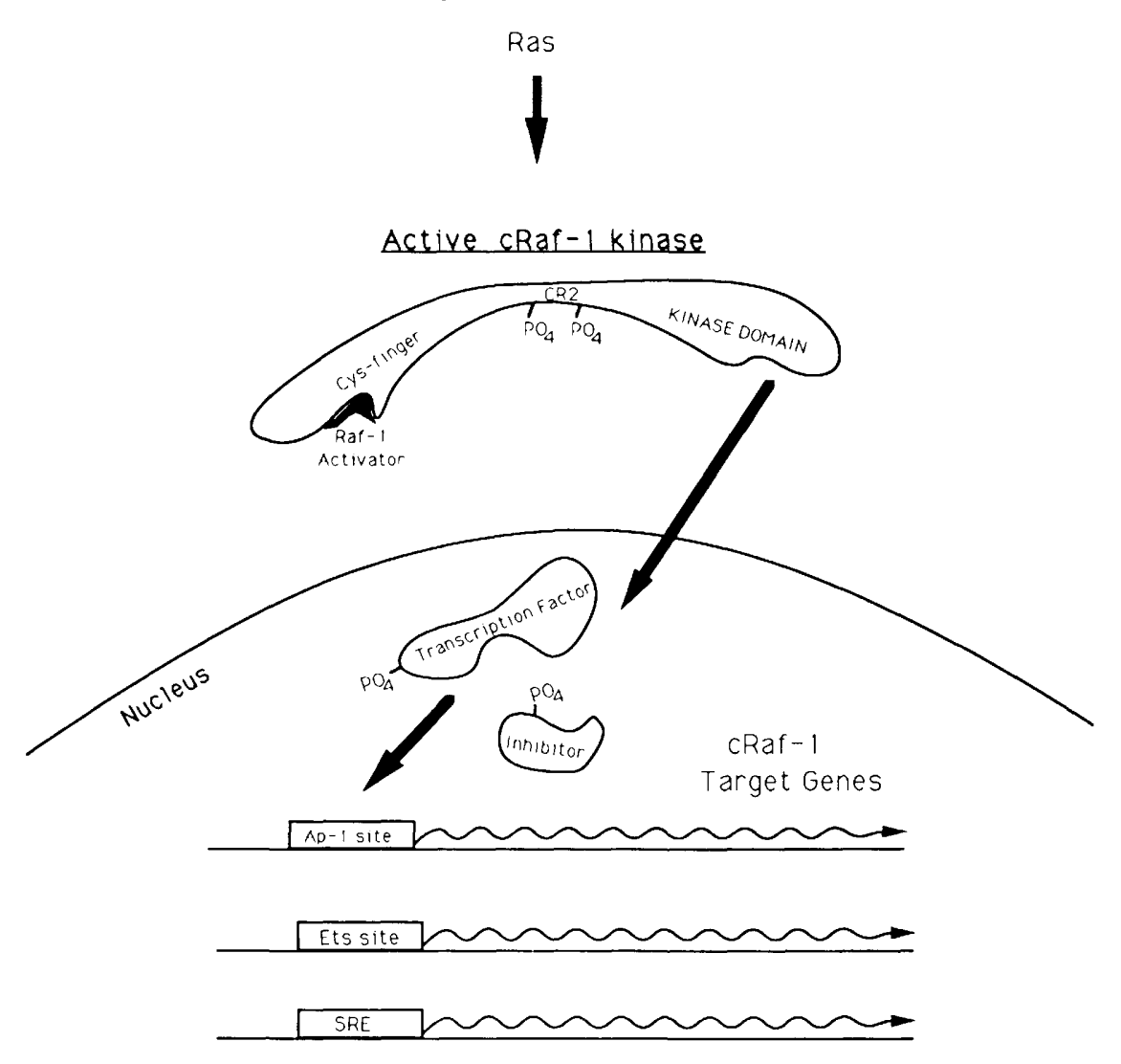

Active cRaf-1 kinase

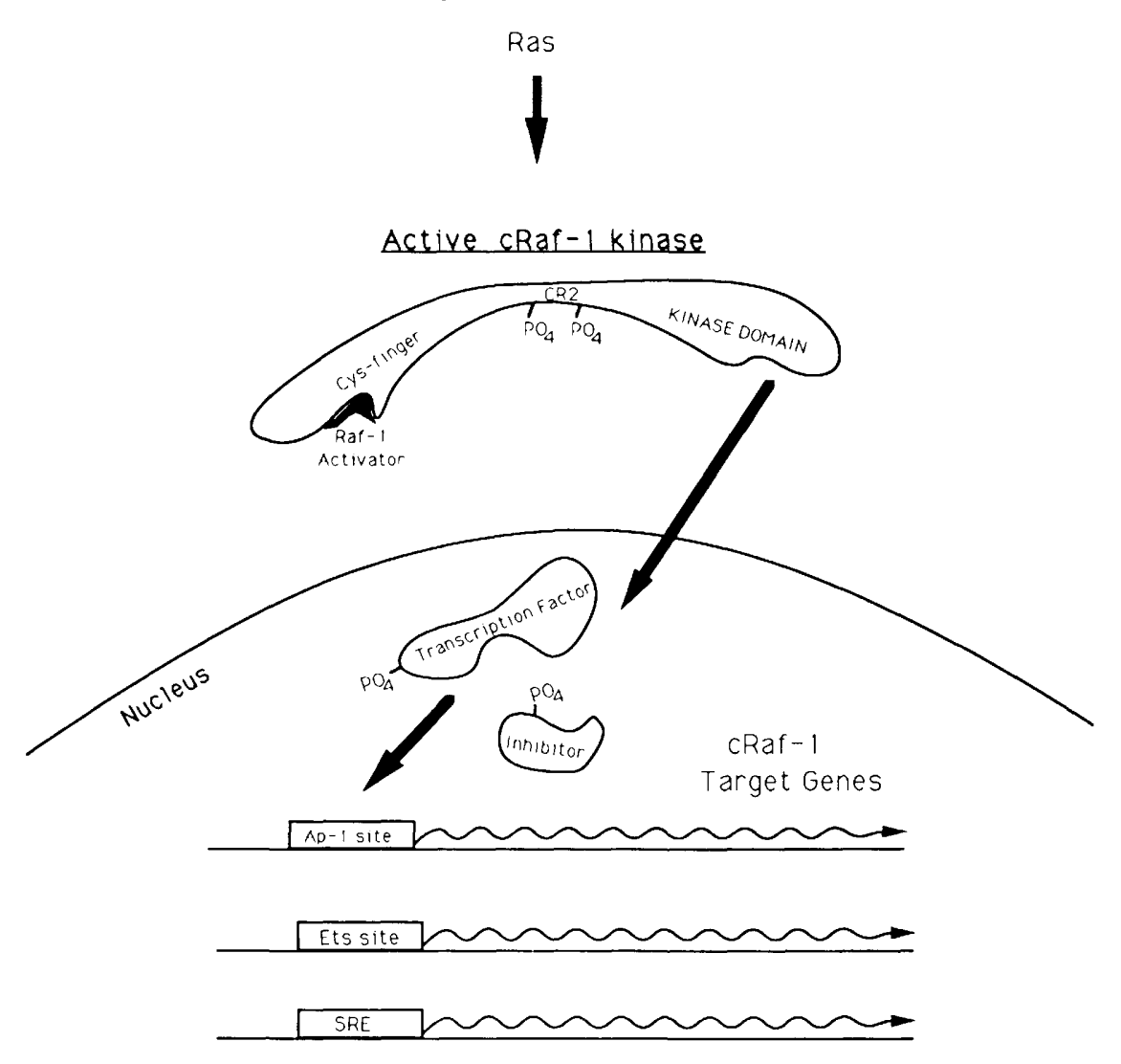

Figure 7. Schematic model for Raf-1 activation. Negative regulation of Raf- 1 in quiescent cells is achieved through repressive intramolecular interactions. Inhibition is relieved by a Raf-1-activating factor induced by Ras, following serum and TPA stimulation. This activating factor interacts with the cysteine finger region of Raf1. Following activation, Raf-1 phosphorylates substrate factors involved in the transcriptional activation of target genes that control cell growth. 


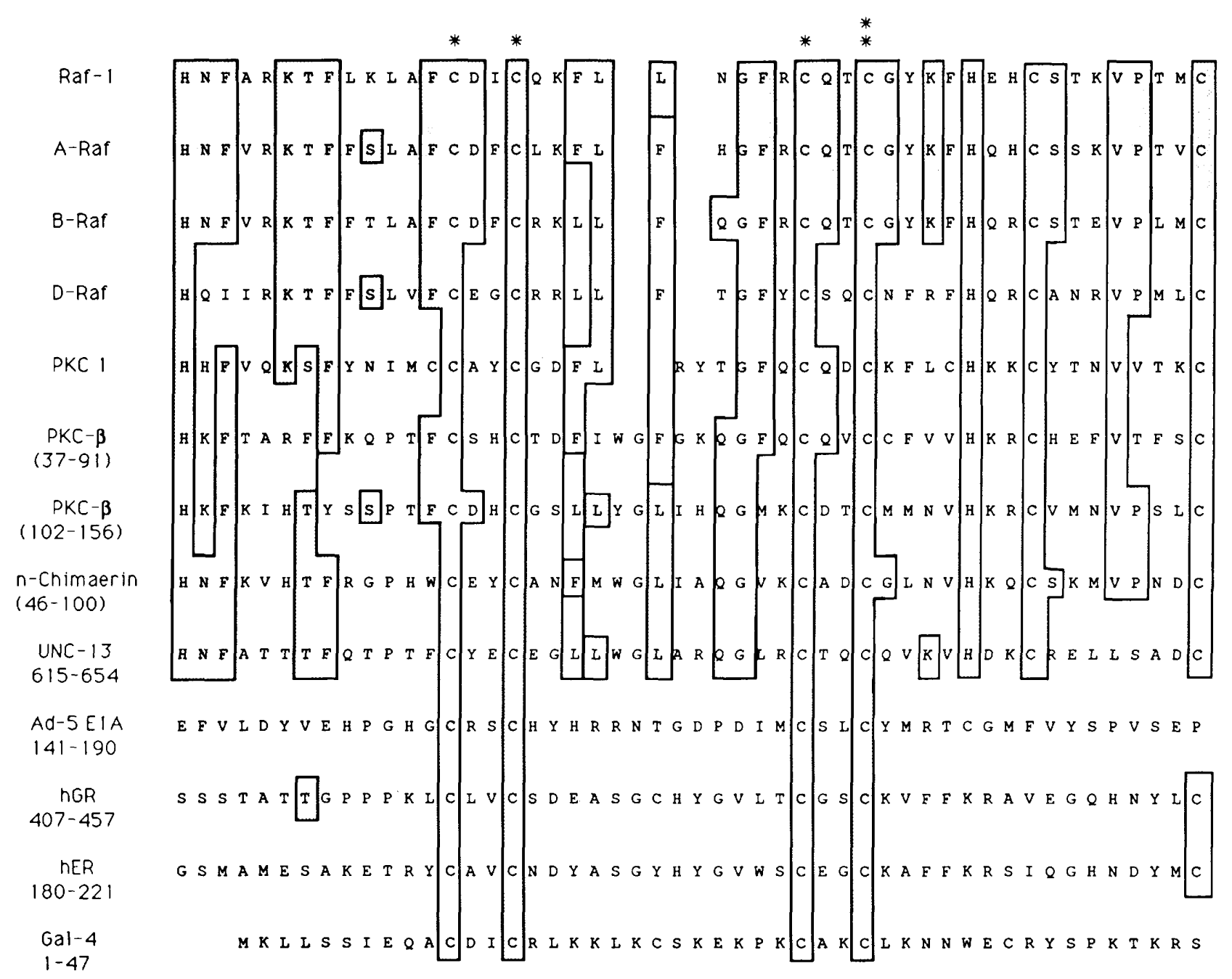

Figure 8. Comparison of the cysteine-rich domains of Raf family members (Bonner et al. 1985; Beck et al. 1987; Nishida et al. 1988; Sithanandam et al. 1990), yeast PKC-1 (Levin et al. 1990), human PKC- $\beta$ (Coussens et al. 1986), n-chimaerin (Hall et al. 1990), the unc-13 gene product (Maruyama and Brenner 1991), adenovirus type $5 \mathrm{E} 1 \mathrm{~A}$ (Martin et al. 1990), human estrogen receptor (hER; Green et al. 1986), human glucocorticoid receptor (hGR; Hololenberg et al. 1985), and yeast Gal4 (Laughon and Gesteland 1984). Identical amino acids are boxed and shaded. The asterisks indicate conserved cysteine residues; the double asterisk indicates the cysteine residue that was changed to serine in Raf-pml7.

the cysteine finger motif of Raf- 1 and activates the Raf- 1 kinase is a mitogen-induced lipid. However, it is also possible that CR1 mediates protein-protein interactions. Precedents for such a function include the CD4/LCK interaction (Turner et al. 1990) and Tat dimer formation (Frankel et al. 1988). We therefore have to consider that the Raf-1 activator may be a protein or perhaps Raf-1 activation involves dimerization in a fashion analogous to that of receptor tyrosine kinase oligomerization (Ullrich and Schlessinger 1990). Current work in our laboratory is aimed at the identification of the activating factor.

We have shown that Raf-1 and v-Ha-Ras cooperate to activate transcription from the oncogene-responsive element in the polyomavirus enhancer. Cooperation among oncogenes can result from constitutive activation of distinct signaling pathways or from one oncogene product increasing the activity of a second oncogene product in a linear pathway (Hunter 1991). Because the dominant-negative mutant Raf-C4 completely blocks trans-activation by Ras, and activated Raf- 1 mutants Raf-pml7 and Raf-BXB did not cooperate with Ras, the cooperativity in signaling must result from Ras activation of Raf-1 in a single pathway. The alternative, Ras/ Raf synergy resulting from stimulation of complementary pathways appears unlikely as partially activated (Raf-pm17) and fully activated (Raf-BXB) Raf-1, which stimulate the Raf pathway efficiently, did not cooperate with Ras.

Clues to the mechanism by which Raf- 1 may activate transcription of AP-1/Ets-driven genes are beginning to emerge. Recently, it has been shown that Ras cooperates with c-Jun in trans-activation through an Ap-1 site (Binétruy et al. 1991). This cooperativity appears to result from Ras stimulating the activity of a kinase that phosphorylates c-Jun in the trans-activation domain and in- 
creases the transcriptional activity of c-Jun. Because Rasinduced trans-activation of pB4X CAT expression was mediated by Raf-1, it appears likely that the Ras-induced kinase that triggers c-Jun phosphorylation is Raf- 1 . This is consistent with our recent finding that cotransfecting c-Jun and Raf-BXB expression vectors results in an increase in c-Jun phosphorylation (data not shown). Therefore, c-Jun is probably a substrate for Raf- 1 or for a kinase that is activated by Raf-1. Alternatively, Raf-1 may activate $\mathrm{c}$-Jun and other transcription factors by regulating the activity of their negative regulators (Baichwal and Tjian 1990; Ghosh and Baltimore 1990; Auwerx and Sassone-Corsi 1991; Baichwal et al. 1991; Roux et al. 1990).

Transcriptional activation and transformation by Raf appear to be linked, as we have been unable to uncouple these activities by mutation. Moreover, cell lines that conditionally express the inhibitor of transcriptional trans-activation, Raf-C4, display an inducible decrease in growth rate and transformed morphology (K. Muszynski, J. Bruder, and U. Rapp, unpubl.). Proof that transcriptional activation by Raf- 1 is a determinant of cell growth control will require the identification and characterization of the cellular genes that are activated by Raf- 1 in response to mitogenic stimuli.

\section{Materials and methods}

Plasmids and molecular cloning

pKS-crafEX consists of the EcoRI-Xbal fragment of c-raf-1 cDNA clone 628 (Bonner et al. 1986) cloned into Bluescript(KS - 1 . Raf-1-coding sequences from pKS-crafEX were released from the vector following cleavage with $\mathrm{XbaI}$ and ClaI and ligated into the $X b a I$ and ClaI sites of pkRSPA (Dorn et al. 1990), resulting in the expression construct RSV-Raf-1, which was used in experiments presented here. The RSV-Raf expression constructs express Raf- 1 and Raf- 1 mutants from the RSVLTR.

RSV-Raf-1 carboxy-terminal deletion mutants (Raf-Cl, RafC2, Raf-C3, Raf-C4) were generated by cutting RSV-Raf-1 with BglII, SphI, StuI, or SalI, respectively, followed by a repair reaction using Klenow DNA polymerase. $\mathrm{XbaI}$ (nonsense codon) linkers were ligated to the repaired ends, and the Raf-1-coding sequences were released upon cleavage with $\mathrm{XbaI}$ and $\mathrm{ClaI}$. The $X b a I$ and $C l a I$ fragments were then cloned back into the pkRSPA vector. RSV-Raf-C4pml7 was generated in an identical manner using Raf-pm 17 as the parent vector. RSV-Raf-N1 was generated by digesting RSV-Raf-1 with Sall followed by a repair reaction using T4 DNA polymerase. Ncol 12-mer linkers were ligated to the repaired ends such that the Kozak consensus ATG within the linker was in-frame with the remaining Raf-1coding sequences starting at amino acid position 180. The NcoI-XbaI fragment was subsequently cloned into pkRSPA. RSV-Raf-BXB-C2 was generated by digesting RSV-Raf-BXB with SphI, repairing the ends with T4 DNA polymerase, followed by $X b a I$ (nonsense codon) linker ligation. The reaction was then digested with $X b a I$ and religated. Raf-pm 17 was generated by site-directed mutagenesis on a single-stranded copy of pKScrafEX using a mismatched 20-mer primer. To obtain BXB and BXB-301, the PvuII-BglI fragment, encompassing codons 26-302, was deleted from pKScrafEX or pKScraf-301EX, respectively. The BgII end was filled in with T4 DNA polymerase prior to ligation. Raf- 1 -coding sequences from $\mathrm{pm} 17, \mathrm{BXB}$, and $\mathrm{BXB}$ 301 were released from the vector following cleavage with $X b a I$ and $C l a \mathrm{I}$ and ligated into the $X b a \mathrm{I}$ and ClaI sites of pkRSPA, generating RSV-Raf-pm 17, RSV-Raf-BXB, and RSV-Raf-BXB301.

\section{Cells and transfections}

Monolayer cultures of NIH-3T3 cells were grown in Dulbecco's modified Eagle medium containing 10\% fetal calf serum. Monolayer cultures of HepG2 cells were grown in minimum essential medium containing $10 \%$ fetal bovine serum.

DNA transfections were performed by the calcium phosphate precipitation method described by Wigler et al. (1977). Cells $\left(1 \times 10^{6}\right)$ were seeded 1 day prior to transfection. The cells were transfected with $1 \mu \mathrm{g}$ of reporter construct, $5 \mu \mathrm{g}$ of expression vector, and salmon sperm DNA such that the final concentration of DNA was $20 \mu \mathrm{g} /$ transfection. After an overnight incubation, the cells were washed, and fresh media, containing $0.3 \%$ fetal calf serum for NIH-3T3 cells or $0.05 \%$ fetal calf serum for HepG 2 cells, was added. Total cell extracts were prepared $48 \mathrm{hr}$ later, and CAT enzyme levels were assayed by the diffusionbased CAT assay described by the manufacturer (New England Nuclear). Transfections were performed numerous times with two different plasmid DNA preparations.

\section{Acknowledgments}

We are grateful to Thomas Shih for kindly providing Ras expression vectors, Bohdan Wasylyk for the $\mathrm{pB} 4 \mathrm{X}$ and $\mathrm{pAB} 4 \mathrm{X}$ CAT vectors, Peter Angel and Michael Karin for 3X-TRE CAT, and David Derse for pkRSPA. We thank Fuh-Mei Duh for excellent technical assistance. We also thank Douglas Lowy, Tom Beck, Jakob Troppmair, and Steven Storm for critical reading of the manuscript.

The publication costs of this article were defrayed in part by payment of page charges. This article must therefore be hereby marked "advertisement" in accordance with 18 USC section 1734 solely to indicate this fact.

\section{References}

Ahmed, S., R. Kozma, C. Monfries, C. Hall, H.H. Lim, P. Smith, and L. Lim. 1990. Human brain n-chimaerin cDNA encodes a novel phorbol ester receptor. Biochem. 1. 272: 767-773.

Angel, P., M. Imagawa, R. Chiu, B. Stein, R.J. Imbra, H.J. Rahmsdorf, C. Jonat, P. Herrlich, and M. Karin. 1987. Phorbol ester-inducible genes contain a common cis element recognized by a TPA-modulated trans-acting factor. Cell 49: 729-739.

Auwerx, J. and P. Sassone-Corsi. 1991. IP-1: A dominant inhibitor of Fos/Jun whose activity is modulated by phosphorylation. Cell 64: 983-993.

Baichwal, V.R. and R. Tjian. 1990. Control of c-Jun activity by interaction of a cell-specific inhibitor with regulatory domain delta: Differences between v- and c-Jun. Cell 63: 815825.

Baichwal, V.R., A. Park, and R. Tjian. 1991. v-Src and EJ Ras alleviate repression of c-Jun by a cell-specific inhibitor. $\mathrm{Na}$ ture 352: 165-168.

Bar-Sagi, D. and J.R. Feramisco. 1986. Induction of membrane ruffling and liquid-phase pinocytosis in quiescent fibroblasts by ras proteins. Science 233: 1061-1068.

Beck, T.W., M. Huleihel, M. Gunnell, T.I. Bonner, and U.R. Rapp. 1987. The complete coding sequence of the human 
A-raf- 1 oncogene and transforming activity of a human A-raf carrying retrovirus. Nucleic Acids Res. 15: 595-609.

Binétruy, B., T. Smeal, and M. Karin. 1991. Ha-Ras augments c-Jun activity and stimulates phosphorylation of its activation domain. Nature 351: 122-127.

Bonner, T.I., H. Oppermann, P. Seeburg, S.B. Kerby, M.A. Gunnell, A.C. Young, and U.R. Rapp. 1986. The complete coding sequence of the human raf oncogene and the corresponding structure of the c-raf-1 gene. Nucleic Acids Res. 14: 10091015.

Bourne, H.R. and A.L. DeFranco. 1989. Signal transduction and intracellular messengers. In Oncogenes and the molecular origins of cancer (ed. R.A. Weinberg), pp. 97-124. Cold Spring Harbor Laboratory Press, Cold Spring Harbor, New York.

Bruder, J.T. and P. Hearing. 1989. Nuclear factor EF-lA binds to the adenovirus core enhancer element and to other transcriptional control regions. Mol. Cell. Biol. 9: 5143-5153.

Cai, H., J. Szeberényi, and G.M. Cooper. 1990. Effect of a dominant inhibitory Ha-ras mutation on mitogenic signal transduction in NIH 3T3 cells. Mol. Cell. Biol. 10: 5314-5323.

Clanton, D.J., Y. Lu, D.G. Blair, and T.Y. Shih. 1987. Structural significance of the GTP-binding domain of ras p21 studied by site-directed mutagenesis. Mol. Cell. Biol. 7: 3092-3097.

Coussens, L., P.J. Parker, L. Rhee, T.L. Yang-Feng, E. Chen, M.D. Waterfield, U. Francke, and A. Ulrich. 1986. Multiple, distinct forms of bovine and human protein kinase C suggest diversity in cellular signaling pathways. Science 233: 859866.

Dorn, P., L. DaSilva, L. Martarano, and D. Derse. 1990. Equine infectious anemia virus tat: Insights into the structure, function, and evolution of lentivirus trans-activator proteins. $/$. Virol. 64: 1616-1624.

Fleischman, L.F., S.B. Chahwala, and L. Cantley. 1986. Rastransformed cells: Altered levels of phosphatidylinositol4,5-bisphosphate and catabolites. Science 231: 407-410.

Frankel, A.D., D.S. Bredt, and C.O. Pabo. 1988. Tat protein from human immunodeficiency virus forms a metal-linked dimer. Science 240: 70-73.

Ghosh, S. and D. Baltimore. 1990. Activation in vitro of NF- $\mathrm{B}$ by phosphorylation of its inhibitor IкB. Nature 344: 678682.

Green, S., P. Walter, V. Kumar, A. Krust, J.M. Bornert, P. Argos, and $P$. Chambon. 1986. Human oestrogen receptor cDNA: Sequence, expression and homology to v-erb-A. Nature 320: $134-139$.

Hall, C., C. Monfries, P. Smith, H.H. Lim, R. Kozma, S. Ahmed, V. Vanniasingham, T. Leung, and L. Lim. 1990. Novel human brain cDNA encoding a $34,000 \mathrm{Mr}$ protein $\mathrm{n}$-Chimaerin, related to both the regulatory domain of protein kinase $\mathrm{C}$ and $\mathrm{BCR}$, the product of the breakpoint cluster region gene. J. Mol. Biol. 211: 11-16.

Heidecker, G., M. Huleihel, J.L. Cleveland, W. Kolch, T.W. Beck, P. Lloyd, T. Pawson, and U.R. Rapp. 1990. Mutational activation of c-raf- 1 and definition of the minimal transforming sequence. Mol. Cell. Biol. 10: 2503-2512.

Hololenberg, S.M., C. Weinberger, E.S. Ong, G. Cerelli, A. Oro, R. Lebo, E.B. Thompson, M.G. Rosenfeld, and R.M. Evens. 1985. Primary structure and expression of a functional human glucocorticoid receptor cDNA. Nature 318: 635-64l.

Huleihel, M., M. Goldsborough, M. Gunnell, J.L. Cleveland, T.I. Bonner, and U.R. Rapp. 1986. Characterization of murine a-raf, a new oncogene related to the v-raf oncogene. Mol. Cell. Biol. 6: 2655-2662.

Hunter, T. 1991. Cooperation between oncogenes. Cell 64: 249270.
Jamal, S. and E. Ziff. 1990. Transactivation of c-fos and betaactin genes by raf as a step in early response to transmembrane signals. Nature 344: 463-466.

Kaibuchi, K., Y. Fukumoto, N. Oku, Y. Hori, T. Yamamoto, K. Toyoshima, and Y. Takai. 1989. Activation of the serum response element and 12-O-tetradecanoylphorbol-13-acetate response element by the activated c-raf- 1 protein in a manner independent of proteine kinase C. J. Biol. Chem. 264: 20855-20858.

Kolch, W., G. Heidecker, P. Lloyd, and U.R. Rapp. 1991. Raf-1 protein kinase is required for growth of induced NIH/3T3 cells. Nature 349: 426-428.

Lacal, J.C., J. Moscat, and S.A. Aaronson. 1987. Novel source of 1,2-diacylglycerol elevated in cells transformed by Ha-ras oncogene. Nature 330: 269-272.

Laughon, A. and R.F. Gesteland. 1984. Primary structure of the Saccharomyces cerevisiae GAL4 gene. Mol. Cell. Biol. 4: 260-267.

Lee, R., M.H. Cobb, and P. Blackshear. 1991. Evidence that extracellular signal-regulated kinases (ERKs) are the insulinactivated Raf-1 kinase kinases. I. Biol. Chem. 267: 10881092.

Levin, D.E., O. Fields, J. Kunisawa, J.M. Bishop, and J. Thorner. 1990. A candidate protein kinase $\mathrm{C}$ gene, $\mathrm{PKCl}$, is required for the S. cerevisiae cell cycle. Cell 62: 213-224.

Martin, K.J., J.W. Lillie, and M.R. Green. 1990. Evidence for interactions of different eukaryotic transcriptional activators with distinct cellular targets. Nature 346: 147-152.

Maruyama, I.N. and S. Brenner. 1991. A phorbol ester/diacylglycerol-binding protein encoded by the unc-13 gene of Caenorhabditis elegans. Proc. Natl. Acad. Sci. 88: 5729-5733.

Morrison, D.K., D.R. Kaplan, U.R. Rapp, and T.M. Roberts. 1988. Signal transduction from membrane to cytoplasm: Growth factors and membrane-bound oncogene products increase Raf-1 phosphorylation and associated proteine kinase activity. Proc. Natl. Acad. Sci. 85: 8855-8859.

Mulcahy, L.S., M.R. Smith, and D.W. Stacey. 1985. Requirement for ras proto-oncogene function during serum-stimulated growth of NIH 3T3 cells. Nature 313: 241-243.

Nishida, Y., M. Hata, T. Ayaki, H. Ryo, M. Yamagata, K. Shimizu, and Y. Nishizuka. 1988. Proliferation of both somatic and germ cells is affected in the Drosophila mutants of raf proto-oncogene. $E M B O$ I. 7: 775-781.

Noda, M., Z. Selinger, E.M. Scolnick, and R.H. Bassin. 1983. Flat revertants isolated from Kirsten sarcoma virus-transformed cells are resistant to the action of specific oncogenes. Proc. Natl. Acad. Sci. 80: 5602-5606.

Olah, Z., S. Komoly, N. Nagashima, F. Joo, U.R. Rapp, and W.B. Anderson. 1991. Cerebral ischemia induces transient intracellular redistribution and intranuclear translocation of the raf proto-oncogene product in hippocampal pyramidal cells. Exp. Brain Res. 84: 403-410.

Preiss, J., C.R. Loomis, W.R. Bishop, R. Stein, J.E. Niedel, and R.M. Bell. 1986. Quantitative measurement of sn-1,2-diacylglycerols present in platelets, hepatocytes, and ras- and sistransformed normal rat kidney cells. I. Biol. Chem. 261: 8597-8600.

Qureshi, S.A., M. Rim, J. Bruder, W. Kolch, U. Rapp, V.P. Sukhatme, and D.A. Foster. 1991. An inhibitory mutant of c-Raf-1 blocks v-Src-induced activation of the Egr-1 promoter. J. Biol. Chem. 266: 20594-20597.

Rapp, U.R. 1991. Role of Raf-1 serine/threonine protein kinase in growth factor signal transduction. Oncogene 6: 495-500.

Rapp, U.R., G. Heidecker, M. Huleihel, J.L. Cleveland, W.C. Choi, T. Pawson, J.N. Ihle, and W.B. Anderson. 1988a. raf family serine/threonine protein kinases in mitogen signal 


\section{Bruder et al.}

transduction. Cold Spring Harbor Symp. Quant. Biol. 53: $173-184$.

Rapp, U.R., J.L. Cleveland, T.I. Bonner, and S.M. Storm. 1988b. The raf oncogenes. In The oncogene handbook led. E.P Reddy, A.M. Salka, and T. Curran), pp. 215-253. Elsevier, The Netherlands.

Roux, P., J. Blanchard, A. Fernandez, N. Lamb, P. Jeanteur, and M. Piechaczyk, M. 1990. Nuclear localization of c-Fos, but not v-Fos proteins, is controlled by extracellular signals. Cell 63: $341-351$.

Sithanandam, G., W. Kolch, F. Duh, and U.R. Rapp. 1990. Complete coding sequence of a human B-raf cDNA and detection of B-raf protein kinase with isozyme specific antibodies. Oncogene 5: 1775-1780.

Smith, M.R., S.J. DeGudicibus, and D.W. Stacey. 1986. Requirement for c-ras proteins during viral oncogene transformation. Nature 320: 540-543.

Stanton, V.P., D.W. Nichols, A.P. Laudano, and G.M. Cooper. 1989. Definition of the human raf amino-terminal regulatory region by deletion mutagenesis. Mol. Cell. Biol. 9: 639647.

Turner, J.M., M.H. Brodsky, B.A. Irving, S.D. Levin, R.M. Perlmutter, and D.R. Littman. 1990. Interaction of the unique $\mathrm{N}$-terminal region of tyrosine kinase p56lck with cytoplasmic domains of CD4 and CD8 is mediated by cysteine motifs. Cell 60: 755-765.

Ullrich, A. and J. Schlessinger. 1990. Signal transduction by receptors with tyrosine kinase activity. Cell 61: 203-212.

Wasylyk, C., J.L. Imler, and B. Wasylyk. 1988. Transforming but not immortalizing oncogenes activate the transcription factor PEAl. EMBO /. 7: 2475-2483.

Wasylyk, C., B. Wasylyk, G. Heidecker, M. Huleihel, and U.R. Rapp. 1989a. Expression of raf oncogenes activates the PEAl transcription factor motif. Mol. Cell. Biol. 9: 2247-2250.

Wasylyk, C., P. Flores, A. Gutman, and B. Wasylyk. 1989b. PEA 3 is a nuclear target for transcription activation by nonnuclear oncogenes. EMBO /. 8: 3371-3378.

Wasylyk, B., C. Wasylyk, P. Flores, A. Begue, D. Leprince, and D. Stehelin. 1990. The c-ets proto-oncogenes encode transcription factors that cooperate with c-Fos and c-Jun for transcriptional activation. Nature 346: 191-193.

Wigler, M., S. Silverstein, L.S. Lee, L. Pellicer, Y.C. Cheng, and R. Axel. 1977. Transfer of purified herpes simplex virus thymidine kinase gene to cultures mouse cells. Cell 11:223232. 


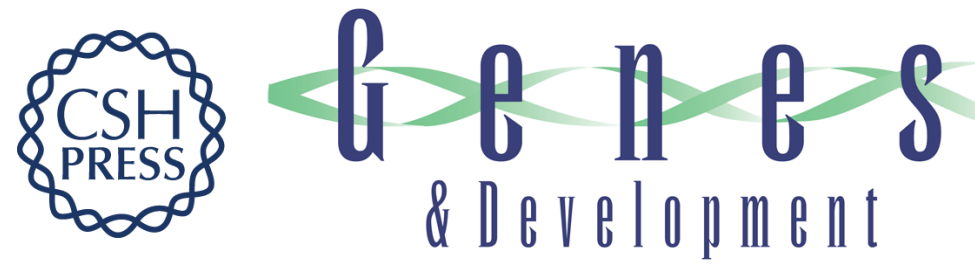

\section{Serum-, TPA-, and Ras-induced expression from Ap-1/Ets-driven promoters requires Raf-1 kinase.}

J T Bruder, G Heidecker and U R Rapp

Genes Dev. 1992, 6:

Access the most recent version at doi:10.1101/gad.6.4.545

References This article cites 52 articles, 21 of which can be accessed free at: http://genesdev.cshlp.org/content/6/4/545.full.html\#ref-list-1

License

Email Alerting

Service

Receive free email alerts when new articles cite this article - sign up in the box at the top right corner of the article or click here.

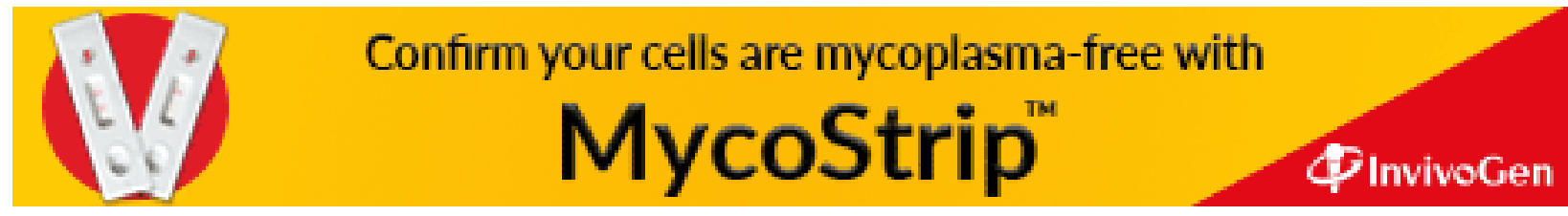

